\title{
Branko Mitrović Andrea Palladio’s Villa Cornaro in Piombino Dese
}

As for many of Palladio's buildings, modern surveys of the Villa Cornaro in Piombino Dese do not exist, are incomplete, omit information about important aspects such as the use of the classical orders, or have been published without dimensions indicated in the plans. The analysis presented here is based on a June 2003 survey of the villa made by Steve Wassell, Tim Ross, Melanie Burke, and author Branko Mitrović. In his treatise, Palladio listed his preferred room types: circular, square or rectangular with length-to-width ratios $2 / 1,3 / 2,4 / 3,5 / 3$ or $\sqrt{ } 2 / 1$. Half a century ago, this kind of speculative search for the comprehensive interpretation of Palladio's proportional system received great impetus from Rudolf Wittkower's Architectural Principles in the Age of Humanism. It is, however, important to differentiate between the derivation of certain proportional rules and their explanation. Wittkower asserted that the use of ornamentation - and especially the orders - did not matter in Palladio's design process. Refuting this theory, Mitrović argues that Palladio, in the early 1550 , formulated a very different approach to the use of the orders, combining the principle of preferred room proportions and the use of a columnar system to determine the placement of walls. The proportions of the main sala and porticos are derived on the basis of the proportional rules for the order used; the proportions of the side rooms on the basis of preferred ratios. Ultimately, the result is that the mathematics of the orders became decisive for Palladio's design principles and the use of proportions from the early 1550 s.

Villa Cornaro in Piombino Dese is one of Andrea Palladio's most influential works (Figs. 1 and 2). ${ }^{1}$ The villa is probably the earliest of his designs to incorporate a pedimented portico separated from the main block of the building - a paradigm whose invention is often associated with Palladio and which has had a huge impact on world architecture for the past four centuries.

The villa was designed in the winter of 1551-1552 and its main block with the exception of the side wings was inhabited by 1554 [Lewis 1972; 1975]. The side wings were completed only in 1596 by Vincenzo Scamozzi, although they appear in Palladio's presentation of the villa in his treatise, The Four Books on Architecture (Fig. 3) [Palladio 1990, 1997]. Douglas Lewis, who has done considerable research on the villa's building history, has managed to find documentation which indicates that the central block of the villa was constructed under close supervision of the architect - a fact which makes the villa a particularly important piece of evidence for the study of Palladio's design theory [Lewis 1972, 384-385]. The early 1550s, when the villa was designed and built, were a turning point in Palladio's approach to design. Through the 1540 s most of his works were villas for Vicentine nobles, in which he generally avoided the use of the classical orders or used them unsystematically. But shortly before the Cornaro project, in the late 1540s and early 1550s, while working on the Basilica and the Palazzo Chiericati, Palladio started using the orders not only as façade ornamentation but as the organizing principle of the entire spatial composition of the buildings he designed. Villa Cornaro is thus among the first buildings whose design was 
derived from an approach which emerges after 1550 and derives from a set of complex mathematical considerations. My analysis here will be based on a recent survey of the villa made by Steve Wassell, Tim Ross, Melanie Burke and myself in June 2003.

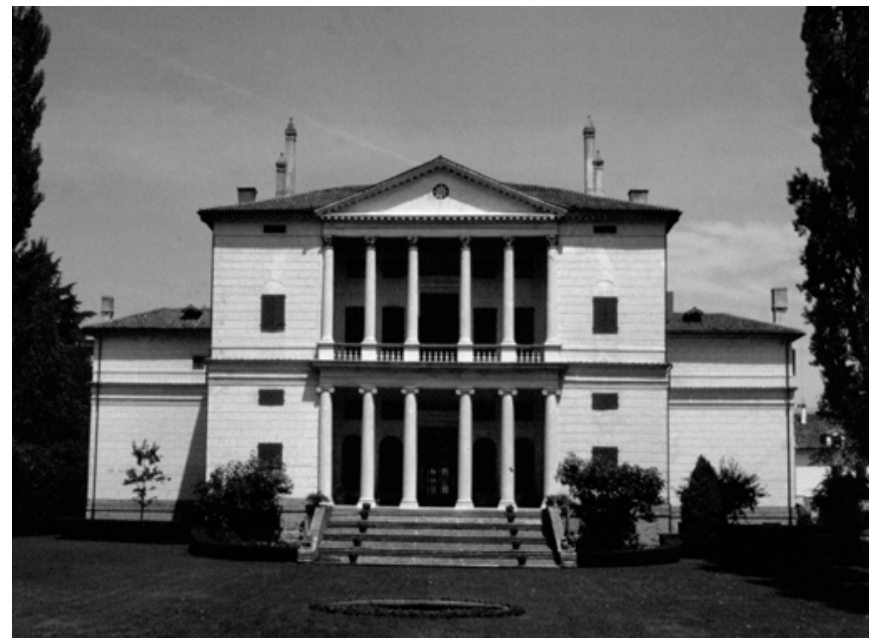

Fig. 1. Villa Cornaro in Piombino Dese, rear (photo/author)

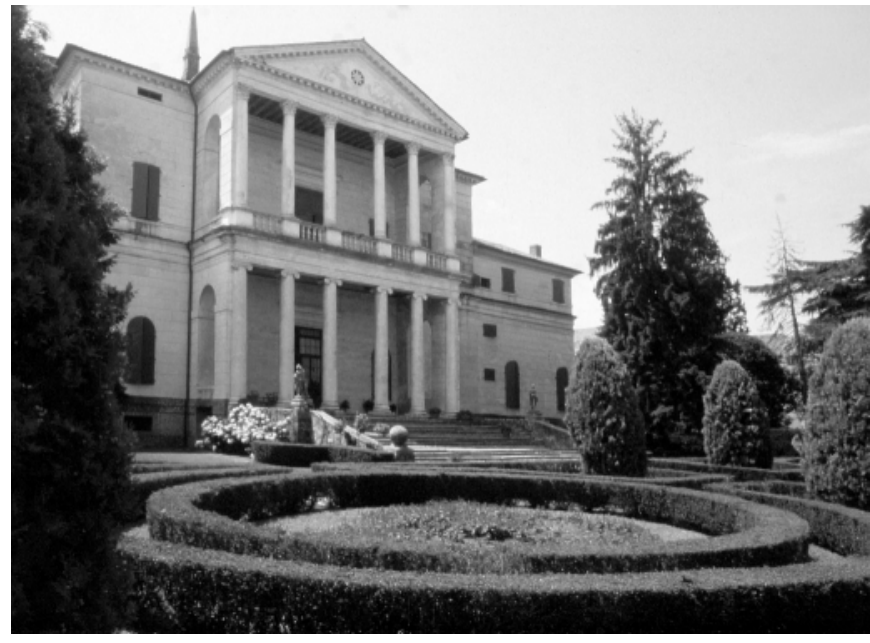

Fig. 2.Villa Cornaro in Piombino Dese, front (photo/author)

The Four Books on Architecture, Palladio's architectural treatise, which came out in 1570 , almost twenty years after Villa Cornaro was designed, is still the most important source for the study of the Vicentine architect's design theory. This may seem paradoxical, considering that Palladio was the most prolific of all great Renaissance architects, and that a great number of the buildings he designed still stand. However, for many of these buildings modern surveys do not exist, are incomplete, omit information about important aspects such as the use of the classical orders, or have been published without dimensions indicated in the plans. 

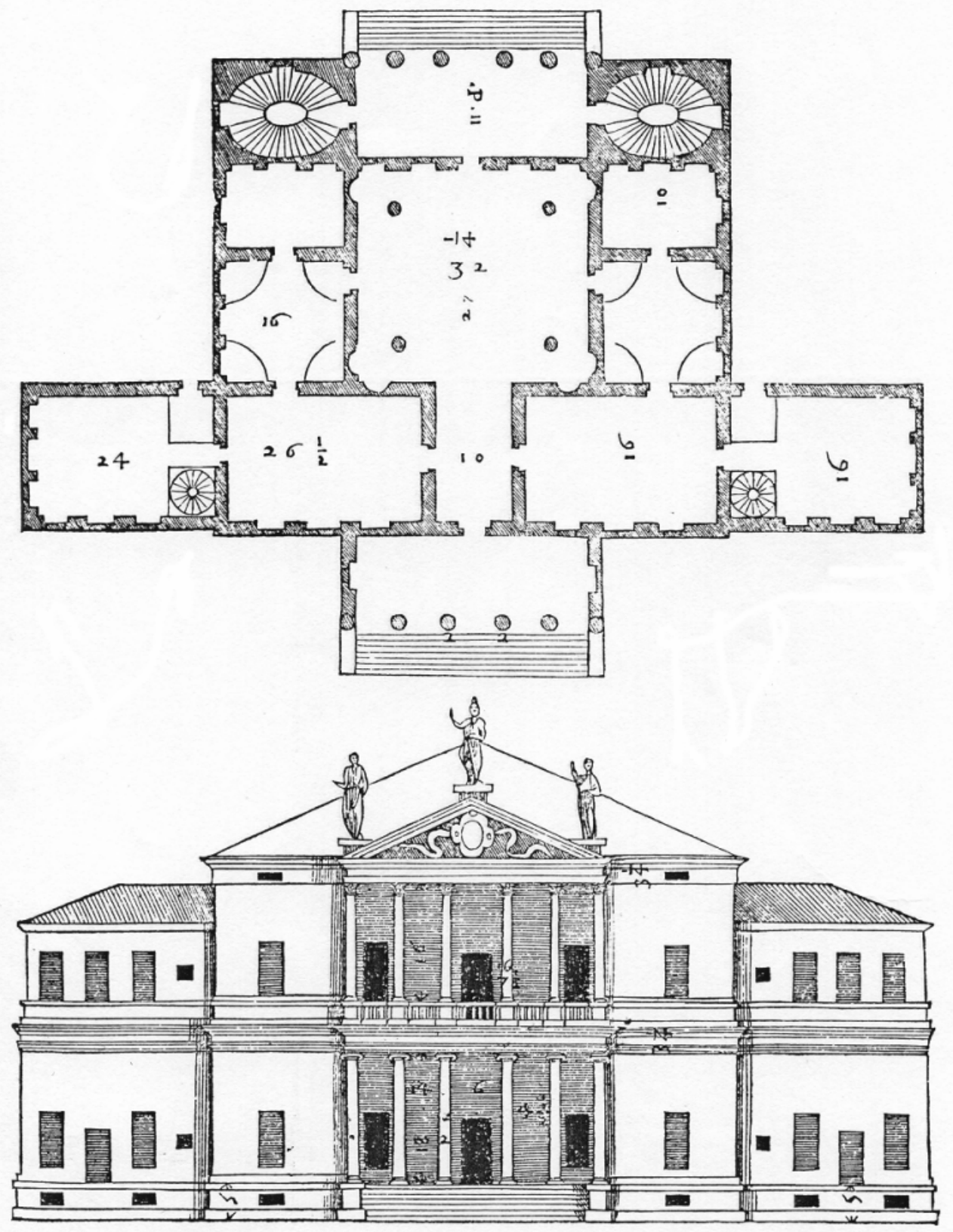

Fig. 3. Villa Cornaro - Palladio's presentation in the Four Books 
The most comprehensive—and I would also argue the most reliable — publicly available set of surveys even today is the one published by Ottavio Bertotti-Scamozzi in the eighteenth century [1968, 1998]. Bertotti-Scamozzi's surveys cover all—or almost all—of Palladio's known opus. Insofar as I have been able to check and compare them with modern surveys, the data he provided tend to be reasonably accurate [Mitrović 2004, 194-197]. He did, however, have a passion for presenting Palladio's unfinished works as if they had been completed—and was even sometimes prone to invent the manner in which they should have been completed. When working with Ottavio Bertotti-Scamozzi's surveys it is always necessary to separate the products of his imagination from the segments of Palladio's works which were really built—but this can be done, and once it is done his surveys become a reliable tool. ${ }^{2}$

In his treatise, Palladio listed his preferred room types: circular, square or rectangular with length-to-width ratios $2 / 1,3 / 2,4 / 3,5 / 3$ or $\sqrt{ } 2 / 1$ [Palladio $1997,1.52$ ]. This list is commonly referred to as the list of Palladio's preferred room length/width ratios. Its interpretation and implications have been in the center of debates within Palladian scholarship for the past 50 years. ${ }^{3}$ In the second book of his treatise Palladio presented plans of forty-four buildings he designed; in these plans, room length-to-width ratios have been indicated for 153 rooms. ${ }^{4}$ Eighty-nine of these 153 ratios-or 55\% -indeed correspond to the ratios from Palladio's list. An analysis of the remaining $45 \%$ shows that some other proportional systems were used by the architect as well. The ratio $\sqrt{3} / 1$ appears in a number of plans - most prominently in the plan of the Rotonda-as well as ratios such as $\sqrt{3} / 1, \sqrt[3]{2} / 1$, and $(\sqrt[3]{2})^{2} / 1$ [Mitrović 2004, 65-70]. One may be tempted to speculate, but it would be impossible to prove, whether there could have existed some background theory which would have motivated the architect's choice of individual ratios, both those stated in the list and those not mentioned explicitly, but implicitly indicated in the plans of Palladio's buildings presented in the treatise. Could such a theory account for the remaining $45 \%$ of ratios which cannot be explained by Palladio's list? For instance, all three ratios I have just mentioned, $\sqrt{3} / 1, \sqrt[3]{2} / 1$, and $(\sqrt[3]{2})^{2} / 1$, as well as one ratio from the list of preferred ratios, $\sqrt{2} / 1$, can be seen as cube-derived. $\sqrt{2} / 1$ is the diagonal-to-side ratio of a square, $\sqrt{3} / 1$ is diagonal-to-side ratio of a cube. $\sqrt[3]{2} / 1$ and $(\sqrt[3]{2})^{2} / 1$ are the solutions to the Delian problem of doubling the cube: if $a$ is a side of a given cube, $\sqrt[3]{2} / 1$ will be the side of the cube which has twice its volume and $(\sqrt[3]{2})^{2} / 1$ will be the ratio of the side areas of these two cubes. The Delian problem and methods for solving it were known to Palladio-for instance, they are discussed in Daniele Barbaro's commentary on Vitruvius on which Palladio collaborated [Barbaro 1987, 352-366]. It can be entertaining to speculate about the significance of the choice of certain ratios. The Delian problem-to double the size of a cubic altar in his temple-was given to the Delians by Apollo as the condition of his relieving them from plague. As it happens, the plans of the Rotonda published by Palladio in his treatise are really derived from a $\sqrt{3}$ based system, but, if the available surveys are of any value, the proportions of the Rotonda as executed correspond to those of Delian cubes. At the level of speculation one might even argue that the Rotonda was built as an altar to Apollo.

Half a century ago, this kind of speculative search for the comprehensive interpretation of Palladio's proportional system received great impetus from Rudolf Wittkower's Architectural Principles in the Age of Humanism - arguably the most influential twentieth-century book on Renaissance architectural theory. ${ }^{5}$ Wittkower suggested that Palladio's choice of length/width ratios was derived from musical theory. He referred to the fact that ratios of certain musical 
intervals correspond to numerical relationships between the lengths of strings on a monochord. For instance, the ratio $2 / 1$ is the octave, $3 / 2$ is the fifth, $4 / 3$ is the fourth, and so on. Traditionally, the discovery of relationship between individual numerical relationships and musical intervals was ascribed to Pythagoras; later in classical antiquity this led to the development of an extensive system of speculations which some historians have named "the Great Theory". The concepts musica mundana and harmonia mundi relied on the assumption that the same relationships which determine musical intervals also determine the movements of stars and, through astrological influences, affect the events on Earth. This kind of belief was widespread through the Middle Ages and the Renaissance. Leon Battista Alberti explained the beauty of certain proportional relationships between the lengths and widths of rooms by relating these ratios to those of musical theory [Alberti 1966, 1988: Bk. IX, ch. 5]. The great merit of Wittkower's book was that it described the impact of this kind of belief on Renaissance architectural theory. In his book Wittkower pointed out a number of Renaissance sources which made similar references directly or indirectly. In his commentary on Vitruvius, Daniele Barbaro stated several times that those ratios which are pleasant to the ears also delight the eyes [Barbaro 1987, 124; 244; 282]. Palladio himself, although he did not discuss this kind of belief in his treatise, referred indirectly to it in a memorandum pertaining to the Cathedral of Brescia [Palladio 1988, 123].

It is, however, important to differentiate between the derivation of certain proportional rules and their explanation. In the case of Palladio and Barbaro, their statements did not refer to musical proportions in order to deduce which proportions should be used, but only in order to explain an already existing practice. When Wittkower emphasized the importance of the narrative about harmonic proportions for Palladio's architectural theory, he adopted the case-study method. In his book he analyzed only eight out of forty-four Palladio's buildings presented in the Four Books. These were the buildings which indeed best suited his interpretation [Howard and Longair 1982]. But if we look at the larger picture, Wittkower's interpretation can hardly explain Palladio's design process any better then the claim that Palladio simply used ratios from his list of preferred ratios. Out of 153 room length/width ratios from the building plans presented in the second book of Palladio's treatise, ninety-seven can be interpreted as ratios which correspond to musical ratios according to Wittkower's theory; we have seen that this same number is eighty-nine when it comes to the ratios from Palladio's list of preferred ratios. Also, the ratios which Wittkower's theory can explain are more or less the same as those from the list of preferred ratios: only one ratio from this list, $\sqrt{ } 2 / 1$ cannot be explained as harmonic. At the same time, other ratios we have seen that Palladio used, such as $\sqrt{ } 3 / 1$, cannot have a harmonic explanation. Also, room length-to-width ratios are only room length-to-width ratios. The method by which Palladio decided about them cannot be taken for the only, or even the most important, part of his design procedures. A Renaissance architect would have many other design problems to resolve-such as the composition of the façade, the use of the orders, mutual volumetric correlation of internal spaces, and so on. For instance, if we look at the canon of the five orders that Palladio presented in the first of his Four Books, we shall see that in some cases he adopted ratios for the individual elements from the Vitruvian tradition, but in other cases he had to formulate his own proportions for an element [Mitrović 2002]. The most significant element of the orders for which Palladio had to formulate his own proportions was the Corinthian entablature. A systematic comparison of all the proportional relationships on the Corinthian entablature shows that Palladio did not use harmonic proportions in determining its ratios [Mitrović 2001].

Wittkower's was also an ideological position-something we must never forget: by emphasizing the importance of the proportional relationships between room lengths and widths, 
he actually asserted that the use of ornamentation — and especially the orders-did not matter in Palladio's design process. This interpretation of Palladio supported the Modernist approach to design precisely in the years when the Modernist movement needed it the most, and, as I have argued elsewhere, it coincided with the commercial interests of architectural profession in the 1950 s, which substantially contributed to the popularity of Wittkower's book. At the same time, even if Wittkower's interpretation were true, it really explains only Palladio's design procedures when it comes to the proportioning of individual rooms.

In other words, the question of whether Wittkower was right or wrong is ultimately an ephemeral one. Even if he was right, his approach accounts only for a minor segment of the design problems Palladio had to resolve in his work. A comprehensive proportional analysis of a Palladian villa must take much more into account. In his design work, Palladio had many other design problems to resolve besides the length-to-width ratios of individual rooms. Wittkower's theory did not even attempt to explain the totality of proportional relationships between room dimensions, such as the determination of room heights and mutual proportional correlation of individual rooms. Palladio said that the heights of rooms should be the arithmetical, geometrical, or harmonic means of the height and width, if the room is vaulted. If the room is square, its height should be $4 / 3$ of the width, and if the ceiling is flat, the height should equal the width of the room. In Palladio's time, ground-floor rooms - the level at which a villa or a palazzo is entered-would typically have vaulted ceilings, whereas upper storeys would be covered with wooden beams and have flat ceilings. Palladio's plans usually consist of rows of rooms surrounding a sala (in the case of a villa) or a central courtyard (in the case of a palazzo). If we look at the plans presented in the Four Books, there are very few plans in which all room dimensions are different: usually a dimension of one room is repeated as the length or width of another room in the same row. Two neighboring rooms normally have either the same length, or the same width or the length of one room is the width of another. In the Four Books Palladio mentioned the requirement that rooms in the same row should have equal heights and that consequently their proportions must be carefully coordinated [Palladio 1997, 1.54]. It is thus necessary to select such length-to-width ratios that when we calculate the heights of rooms as arithmetic, geometric, or harmonic means of different lengths and widths, the resulting room heights are all equal. This rule can be called the "condition of concordance of heights", or CCH rule. It substantially delimits the possible proportional relationships between rooms in Palladio's designs. If we assume that rooms in the same row have the same widths, and calculate room heights as the arithmetic, geometric, or harmonic means of room lengths and widths, we shall be able to conclude that coordination of room heights is possible if the height/width ratios are 5/4 and $4 / 3$. If the height/width ratio is $5 / 4$, then it will be possible to have a room with a length/width ratio $5 / 3$ next to a room with a length/width ratio $3 / 2$. The requirements for the $\mathrm{CCH}$ rule will be fulfilled and both rooms will have the same height if the height of the former room is the harmonic and the latter the arithmetic mean of length and width. If the height/width ratio is $4 / 3$, the same with be possible for rooms with ratios $2 / 1$ and $5 / 3$. The height of the former would have to be calculated as the harmonic and the latter as the arithmetic mean of length and width. Also, a square room whose width equals the width of these rooms can be placed next to them, since Palladio said that height/width ratio of square rooms should be $4 / 3$. Finally, a room with the length/width ratio $\sqrt{3} / 1$ can be also have height/width ratios very close to $4 / 3$-in the case they are calculated as arithmetic (1.367) or geometric (1.316) means. In Palladio's villa plans indeed one rarely encounters the situation that more than three rooms have been aligned in the same row. Very often, the third room is much smaller than the other two, has a mezzanine above, and a reduced height. 
An analysis of Palladio's works based on the proportions of rooms, is particularly applicable to his villas of the 1540s. These villas do not have orders applied to the façade. In this group belong Villa Godi in Lonedo, Villa Poiana in Poiana Maggore, Villa Saraceno in Finale, Villa Caldogno in Caldogno, and so on. But from the late 1540s and early 1550s Palladio started systematically using the orders in his designs and - together with Palazzo Chiericati, Villa Pisani in Montagnana and the Basilica-Villa Cornaro was one of first major works in which this new approach was manifested. It was in the decades of the 1550s and 1560s that Palladio and Vignola introduced a revolution in the Renaissance use of the classical orders. The standard use of the orders through the Renaissance before Palladio and Vignola implied that columns or pilasters were placed at regular distances and in those positions where internal walls cut the façade. Through the Renaissance it was common to disregard Vitruvius's advice that intercolumniations should not exceed three lower column diameters. In his treatise Vitruvius listed different intercolumniation types: 3 diameters for diastilos, 2.25 diameters for eustilos, 2 diameters for eustylos and 1.25 diameters for picnostylos. Typically, the Renaissance use of the orders before the 1550s relied on the placement of columns in the corners and at places where the internal walls cut the façade. Additional columns or pilasters would be added in order to ensure equal intercolumniations. The approach was regularly combined with disregard of Vitruvius's precepts for intercolumniations. The columns, pilasters and entablatures would completely frame the facade, but the wide intercolumniations result in a visually unpleasant span between columns or pilasters. The intercolumniations on the contemporary works the young Palladio could have seen near Vicenza by far exceeded Vitruvius's recommendations. Intercolumniation-to-diameter ratio on Giovanni Maria Falconetto's Porta Savonarola in Padua is 4.9; on Porta San Giovanni in the same city 5.8; on Michele Sanmicheli's Palazzo Canossa in Verona this ratio is 4.4; on the Villa Trissino it is 5.7 on the ground floor and 7.9 on the facade of the upper floor. Even on those Renaissance buildings which combine freestanding columns with entablatures, for instance on Brunelleschi's Pazzi Chapel, the ratio is 3.5; on Pirro Ligorio's Casino of Pius IV it is 3.7. This approach normally results in large empty wall surfaces and ultimately unsuccessful attempts to establish a visual rhythm on the facade. Before the 1550s, Palladio's use of the orders conformed to this Renaissance practice, in those cases when he used the orders-e.g., Palazzo Civena, Palazzo Iseppo Porto, Palazzo Thiene or Villa Gazzotti in Bertesina.

The placement of columns on the façade was thus an important unresolved problem which Renaissance architecture faced in the mid-cinquecento. The question was whether columns on the facade should be placed in relation to the walls behind (to "express the interior" as we would say today) or should they be placed according to certain rules for intercolumniations, similar to those Vitruvius stipulated. In his Canon of the Five Orders of 1562, Vignola fully endorsed this latter approach. According to Vignola, the architect should apply the orders only after the building has been actually designed and the basic dimensions on the façade have been determined. One should start by dividing the height of the building into a prescribed number of parts to determine the size of the module, which, subsequently, determines the size and disposition of all other elements of the order. In the case of the Doric, the height of the facade is to be divided into 20 parts, one of which will be the module. The thickness of the architrave is then taken to be 1 module, the frieze $1 \frac{1}{2}$ modules, the intercolumniation $5 \frac{1}{2}$ modules, and so on. The building's dimensions have to be determined before the orders are applied.

But Palladio, in the early 1550 , formulated a very different approach to the use of the orders. A survey of the way his use of intercolumniations changed through his career shows that in the early 1550 s he started systematically using intercolumniations of less than 3 diameters, as Vitruvius had suggested [Mitrović 2004, 203-204]. Intercolumniation-to-diameter ratios are 2.75 on the 
Palazzo Chiericati (1550), 2.7 on the Villa Pisani in Montagnana (1552), 2.25 on the Villa Cornaro, 2.4 on the Villa Chiericati in Vancimuglio (1554), 2.3 on the Palazzo Antonini (1556) and so on. With the exception of Villa Sarego, after the year 1550 intercolumniations of more than 3 lower column diameters appear only on those buildings where Palladio's involvement is considered debatable by Palladian scholarship. (Obviously, one must take into account that intercolumniations had to be increased over 3 diameters when it comes to the main entrances, and that upper storeys are likely to have larger intercolumniations, because columns in upper storeys have thinner diameters.)

Palladio's approach differs from Vignola's in that the position of columns for Palladio had to correspond to the position of walls in the interior of the building. At the same time, the position of interior walls was determined by the proportional rules for length/width ratios, and proportional relationships between individual rooms had to satisfy the $\mathrm{CCH}$ rule. Consequently, the two sets of requirements for internal and external proportions had to be mutually coordinated. The proportional coordination of internal and external elements is further complicated by the fact that the internal height ("floor to floor") must equal the sum of column height plus entablature thickness on the façade.

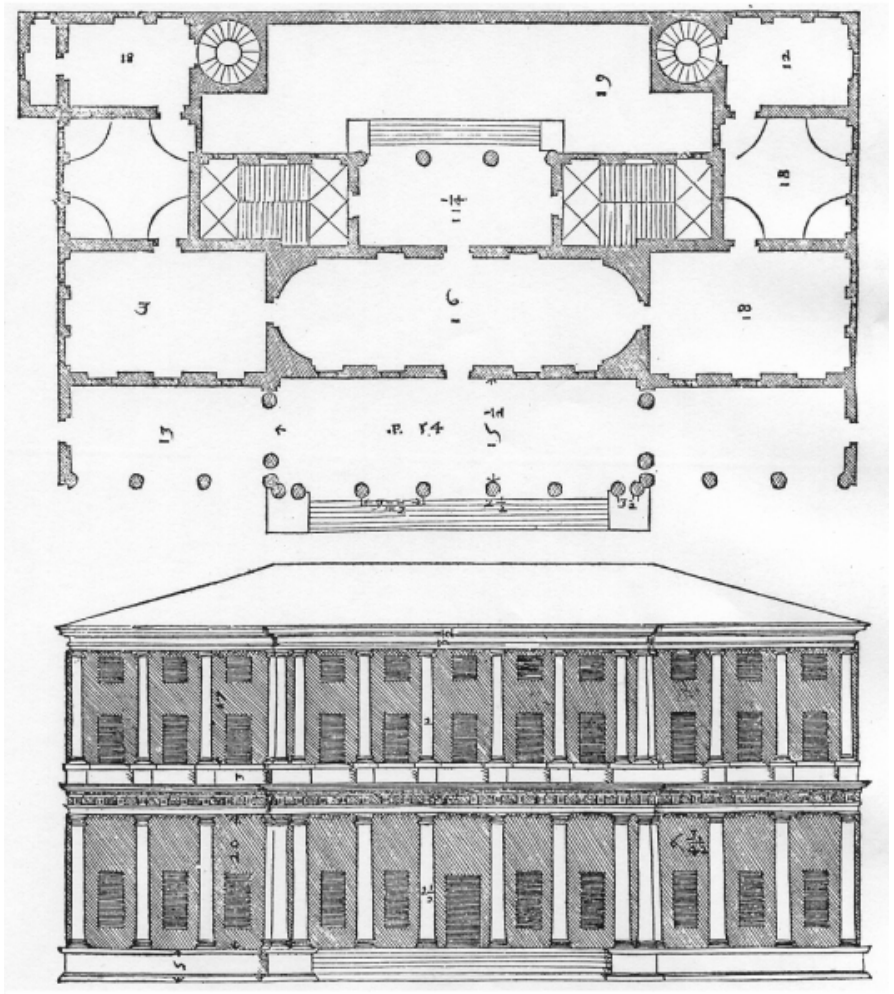

Fig. 4. Palazzo Chiericati - Palladio's presentation in the Four Books

The introduction of these complex mathematical requirements appears for the first time in Palladio's work in the Palazzo Chiericati, at the very beginning of the 1550 s (Fig. 4). According to the Four Books, the large rooms on the side of the central hall are 30 by 18 feet and Palladio says 
that their height was calculated as the arithmetic mean: $(30+18) / 2=24$ feet [Palladio 1997, 2.53]. The next room is square (18 by 18) and vaulted; according to the rule, the height of such rooms equals $4 / 3$ of their width: $4 / 3 \times 18=24$ feet. The height of rooms (calculated as an arithmetic mean to satisfy the $\mathrm{CCH}$ rule) plus the thickness of the ceiling, has to be equal to the height of columns plus entablature thickness. At the same time, the positions of walls have been adjusted to the rhythm of columns. Ground floor intercolumniations on the Chiericati are 2.75 diameters. (One should also note that Palladio's columns never align with the walls exactly-they are always laterally shifted [Mitrović 2004, 112-120]. This strategy appears already in his very earliest works such as Villa Gazotti in Bertesina.)

It is in this context that the proportional system of the Villa Cornaro needs to be analyzed; it was for this reason that we undertook a new surveying campaign. Together with Villa Pisani in Montagnana, Villa Cornaro was designed within two years from Palazzo Chiericati. In this case, the portico has only six columns and it cannot be taken to determine the position of all internal walls orthogonal on the façade (as is the case on the Chiericati), but only of those behind the portico. The size and proportions of the large sala, with its four columns, correspond to the position of the columns in the portico. The sala in this case is a typical Palladian four-column sala with a flat ceiling - a motif Palladio often used. The general morphology of the villa and its volumetrics relates to other Palladian villas of the same period, in whose plans we can similarly read the architect's efforts to align internal bearing elements with the orders on the façade-e.g., Villa Pisani in Montagnana (Fig. 5), Villa Chiericati in Vancimuglio (Fig. 6) and Palazzo Antonini in Udine (Fig. 7).

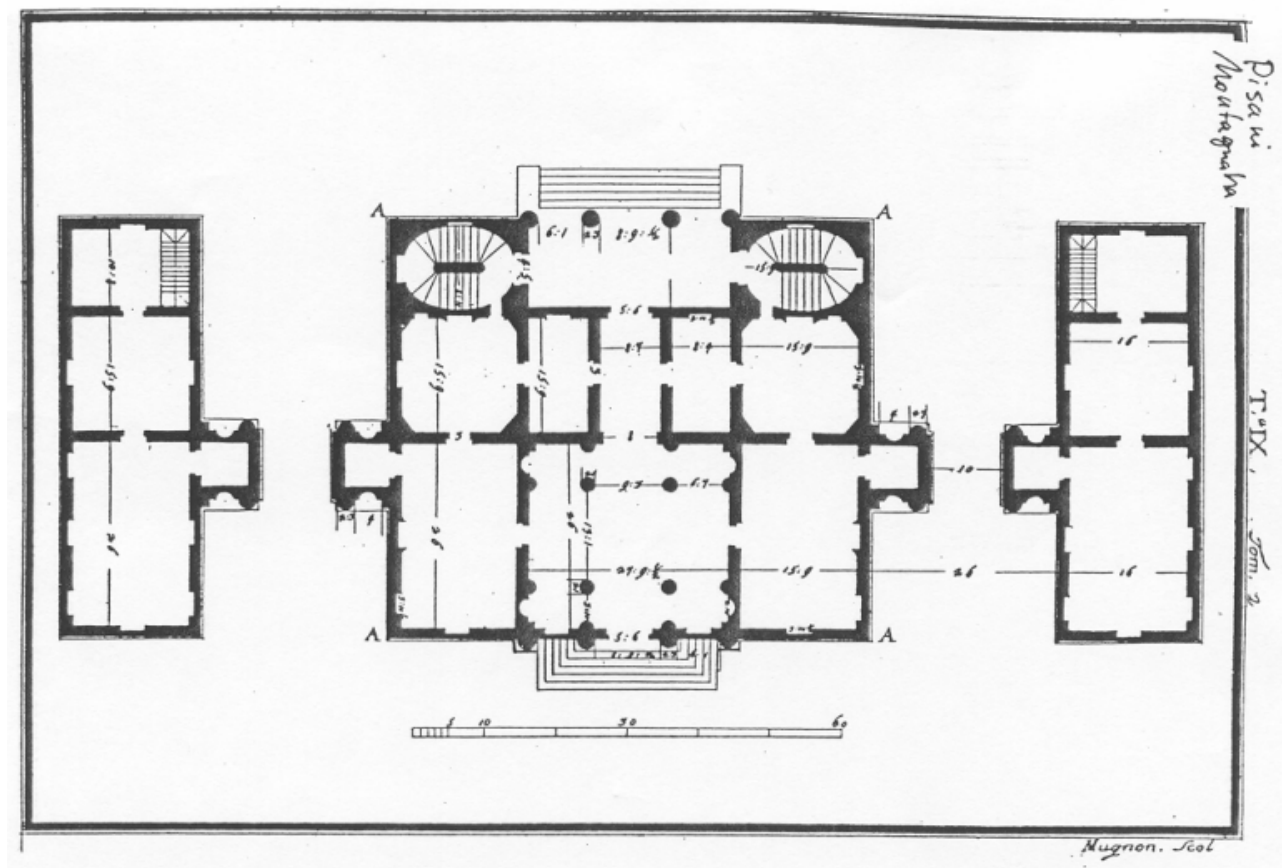

Fig. 5. Villa Pisani in Montagnana. Ottavio Berotti-Scamozzi's survey 


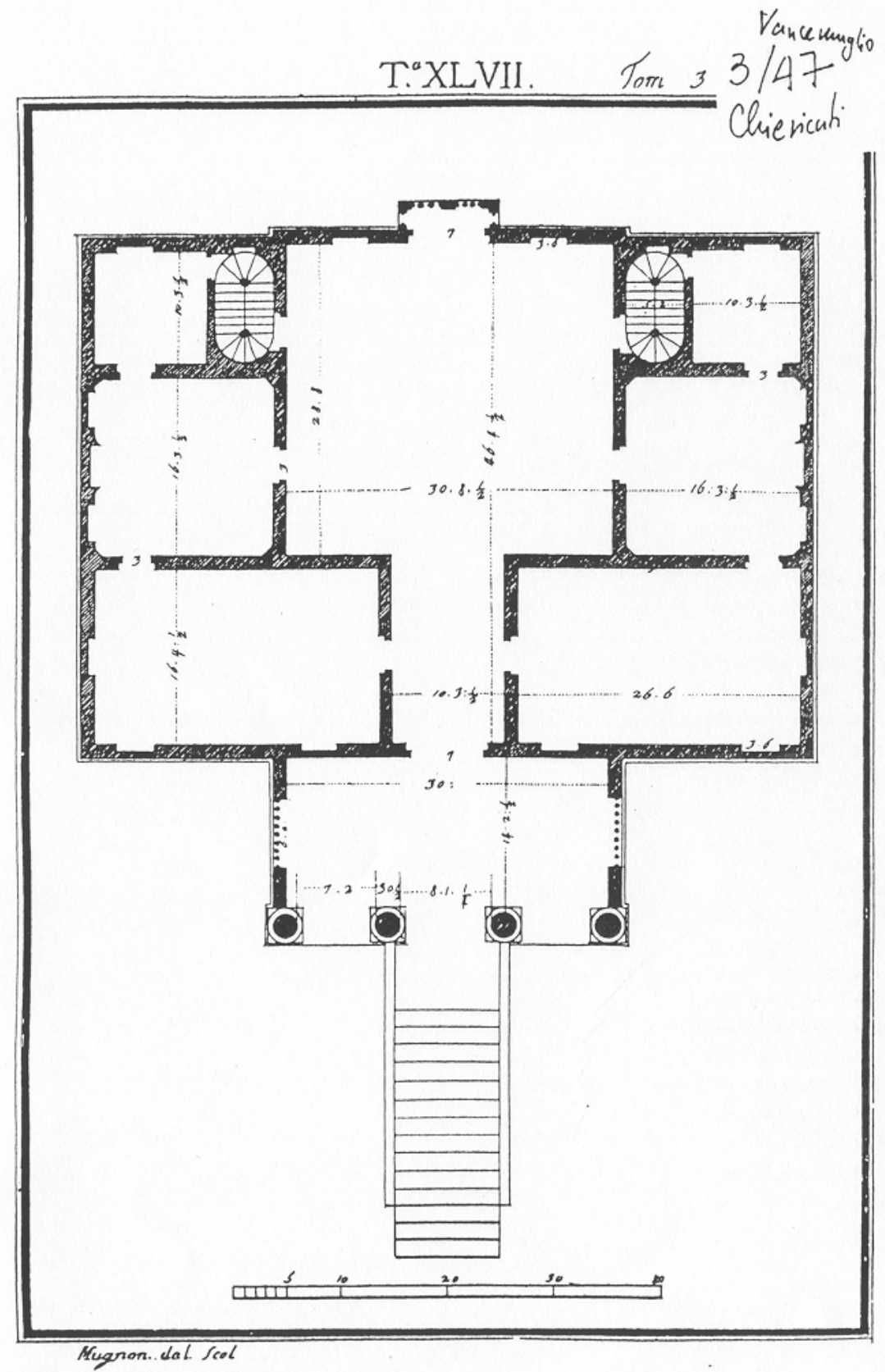

Fig. 6. Villa Chiericati in Vancimuglio. Ottavio Berottti-Scamozzi's survey 


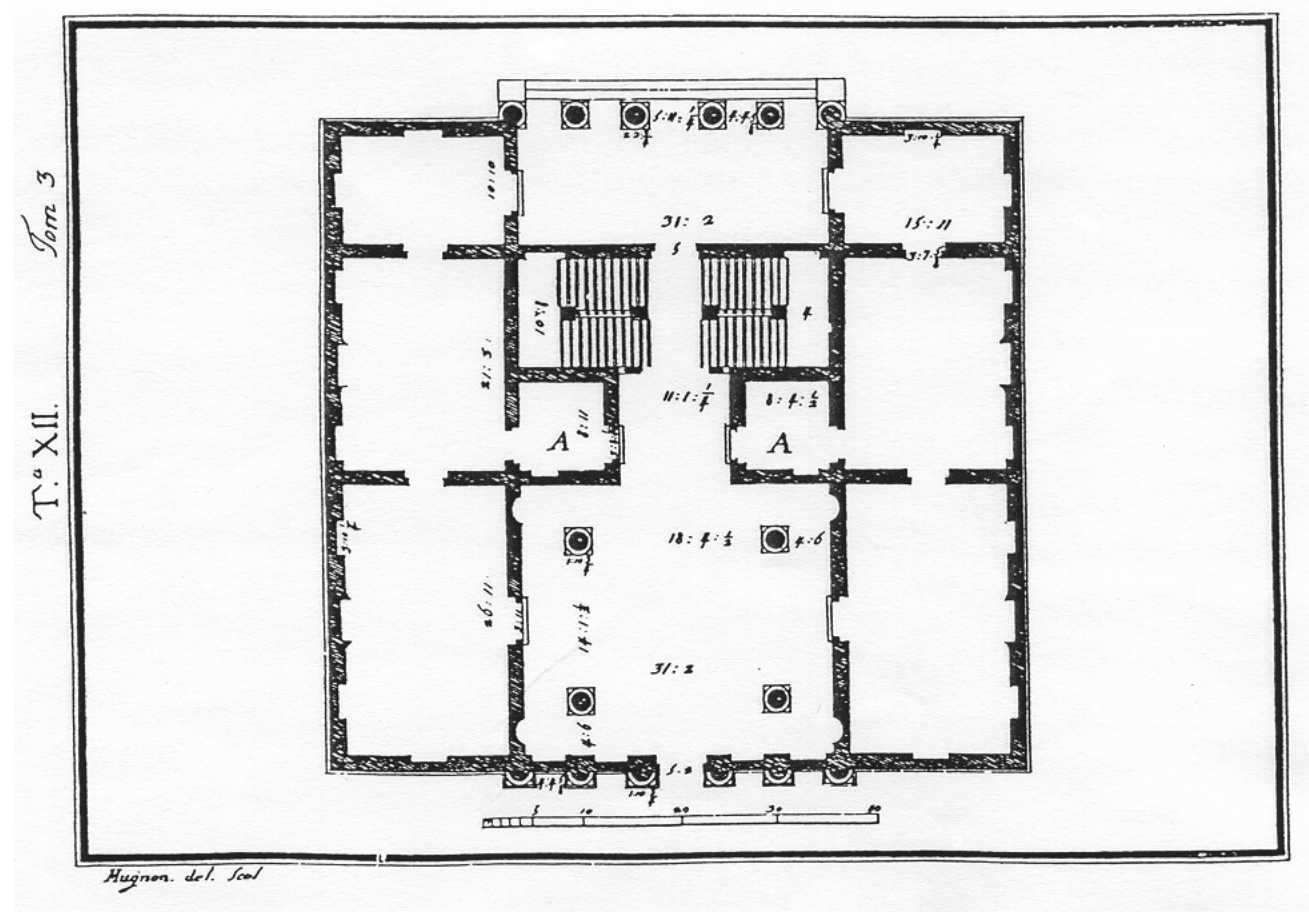

Fig. 7. Palazzo Antonini in Udine. Ottavio Bertotti- Scamozzi's survey

Analyzing the proportional system of an executed building is not the same thing as working with a set of an architect's drawing. ${ }^{6}$ Precision in the execution of a built work can never be great. In the case of Palladio, we can safely rely on considerable precision in stonecutting. Those elements of the orders which were executed in stone show a high level of precision in execution. But when it comes to built walls and masonry work, the level of precision is not nearly so great. One can hardly expect precision greater than $5 \mathrm{~cm}$. The building has also changed in the meantime; some of its parts have been changed and dimensions of rooms have been slightly altered by the addition of new layers to the walls. The heights of rooms are particularly susceptible to even greater imprecision because the floors have been changed in some rooms and because the ornamentation of the ceilings makes it difficult to estimate what Palladio would have considered to be the actual height of individual rooms. It is also recommended that the proportional analysis of side wings added by Scamozzi is left aside-it is not only uncertain in how far these parts of the building correspond to Palladio's intention, but they were also substantially changed in later centuries, unlike the main block of the villa.

The precision in stonecutting allows one to conclude with great certainty that the lower column diameter of ground floor columns was meant to be about $70.3 \mathrm{~cm}$ and plinths are regularly $930 \mathrm{~mm}$. But intercolumniations vary between 152.5 and $157 \mathrm{~cm}$, which gives an intercolumniation-to-diameter ratio between 2.17 and 2.23. Because the columns are Ionic, one is tempted to interpret these ratios as an almost accurate eustylos, which would mean that the architect originally intended intercolumniations to be $2.25 \mathrm{D}$. In that case the optimal intercolumniation would be about $157.5 \mathrm{~cm}$. (The largest measured intercolumniation is $157 \mathrm{~cm}$.) 
The central intercolumniations of the portico are larger-this is typical of Palladio's work and we shall soon see how it was calculated.

The measurements of the rooms on the sides indicate length/width ratios of about 1.7 which is a reasonable approximation of $\sqrt{ } 3$ in built work. The height of these rooms is $717 \mathrm{~cm}$ and can be read as the geometric mean of the length and width. The height/width ratio is about 1.3. In the Four Books Palladio said that the height was the arithmetic mean of the length and width, but this must be a mistake, because in the case the rooms would have to be half a meter higher $(7.65$ $\mathrm{m})$.

The square rooms show how difficult it is to analyze proportionally a survey of an executed building. These rooms were obviously meant to be square-but the difference between their longest and shortest side is $12.5 \mathrm{~cm}$. Quite appropriately for square rooms, the height-to-width ratio is about 1.3. This is a rough approximation of Palladio's rule that the height-to-width ratio of square vaulted rooms should be $4 / 3$. As mentioned before, rooms within the same row in Palladio's designs tend to have one dimension in common. In the case of Villa Cornaro, the width of the larger rooms is the same as the side measurement of the square rooms. Since the ceilings have equal heights and since the height/width ratios of both rooms are equal, one can conclude that the $\mathrm{CCH}$ rule has been successfully applied in Villa Cornaro.

The smallest rooms are the hardest to analyze. Their length/width ratios are between 1.8 and 1.9. Those who have worked with Palladio's proportional system know that he rarely used ratios between $2 / 1$ and $\sqrt{3} / 1$. But it would be difficult to interpret the length/width ratios of these two rooms as one of these two ratios. To do so, one would have to assume inaccuracy in execution of about $30 \mathrm{~cm}$, which is unlikely to happen on both sides of the same building. These smallest rooms have mezzanines above and their ceilings are lower than in other rooms. One should note that the height/width ratio is about $3 / 2$.

The ratios of the large sala also differ from the ratios which Palladio listed in his list of preferred ratios (Fig. 8).

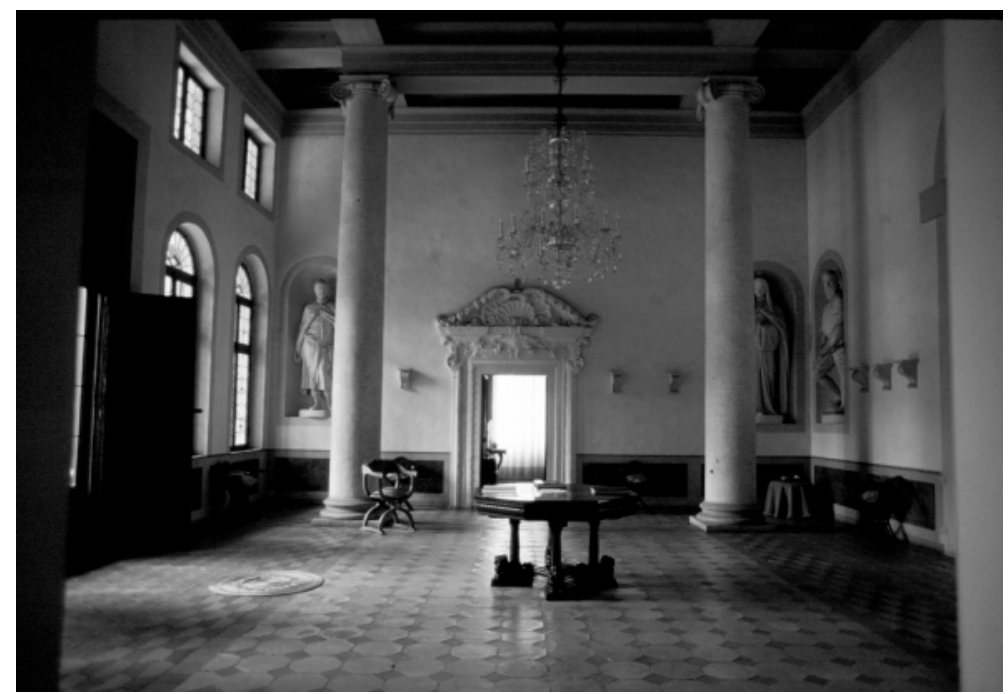

Fig. 8. Villa Cornaro: ground floor sala (photo/author) 
They are not easy to interpret, but it is remarkable that the length/width ratio of the sala is 1.23 whereas width/height ratio is 1.22 . (In this case one should talk about the width/height ratio and not vice versa because the width is greater than the height.) However, if we consider internal length/width ratio-by "internal" I mean here the lengths and widths of the space between the columns - we can see that this ratio is 1.5 or $3 / 2$, one of Palladio's preferred room length/width ratios. The larger distance between the columns equals their height - a point Palladio made himself in the Four Books. Our survey confirms this statement, with some approximation. This ratio now explains the remaining ratios of the sala. The walls, as has been explained, align with the corner columns of the portico, which means that the distance between the walls and the columns of the sala has to be one intercolumniation. This applies to all four walls of the sala. The dimensions of the sala are actually the length and width of the space between four columns (whose length/width ratio is $3 / 2$ ) plus column thickness (diameter) plus intercolumniation. This calculation resulted in the total length and width and produced the sala's length/width ratio of 1.23. The height of the columns (which equals the distance between the columns of the sala) also determines the size of the central portico intercolumniations. The columns of the sala are aligned with the penultimate columns of the portico; the ultimate columns, as we have seen, are aligned with the walls of the sala. The width of the central intercolumniation is the distance between the columns of the sala (i.e., the height of the columns) minus two sums of intercolumniations and column diameters.

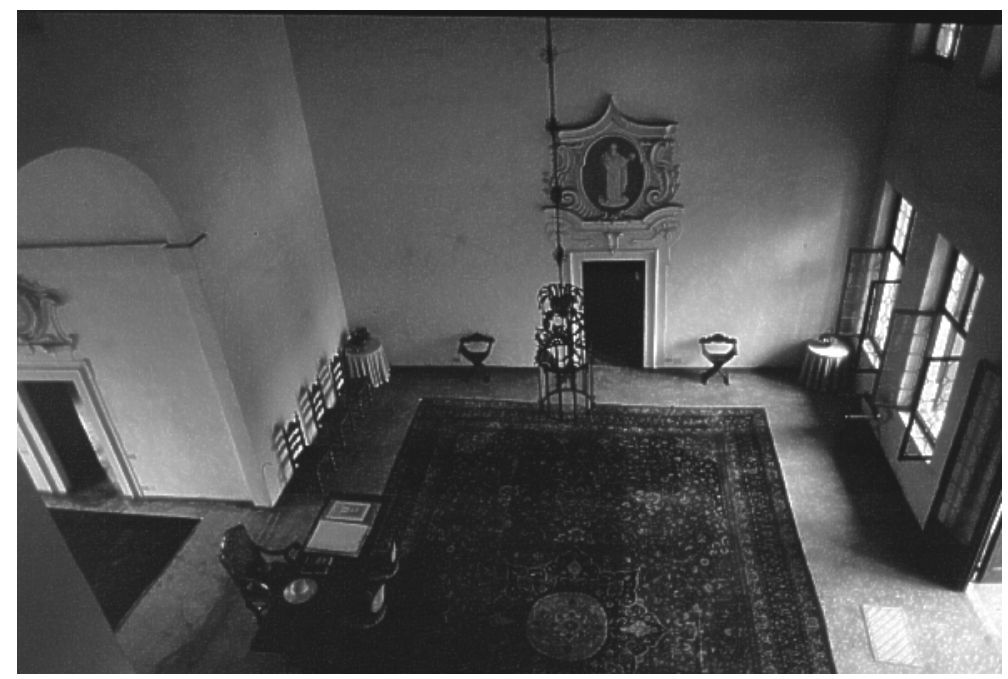

Fig. 9. Upper storey sala (photo/author)

As one would expect, the horizontal proportions of the upper storey closely follow the proportions of rooms at the lower level. The rooms at the upper storey have flat ceilings and, in accordance with Palladio's rules, the ceiling height is (more or less) the same as the width of the rooms. Palladio's tendency to keep one dimension the same for all rooms in a row shows perfect sense in this case-otherwise, walking down a row of rooms on either side, one would note unpleasant changes in ceiling heights. But, when it comes to entering the large sala, the change of ceiling height contributes to the impression of the dignity of space. A remarkable aspect of the large sala on the upper storey is Palladio's dogmatic application of the rule that the height should 
be equal to its width. As a result, the sala is more than nine meters high-an impressive and somewhat daunting space (Fig. 9).

Palladio's approach to design in the Villa Cornaro thus combines the principle of preferred room proportions and the use of a columnar system to determine the placement of walls. The proportions of the main sala and porticos are derived on the basis of the proportional rules for the order used; the proportions of the side rooms on the basis of preferred ratios (or their equivalents, such as $\sqrt{3}$ ) as well as the $\mathrm{CCH}$ rule. In the case of Villa Cornaro, these two separate systems were combined but not intertwined, except in the case of the central space between the columns of the sala. It would be fruitless to attempt to deduce the proportions of the rooms in the side rows from the system of intercolumniations. The distance between the final column of the portico and the end wall of the central block cannot be expressed as the sum of column diameters and intercolumniations. In this sense, Villa Cornaro differs from Palazzo Chiericati. Chiericati has columns across the whole façade and all walls orthogonal to the façade were aligned with these columns. Something similar seems to have been suggested by Palladio on the façade of Villa Pisani in Montagnana. This villa was designed at about the same time as Cornaro and the two villas have very similar morphology. The interesting feature of this villa is the entablature which extends around the villa, even along those walls which have no columns (Fig. 10). The order of the ground floor is Doric and the triglyphs can be taken to indicate the positions where columns should be placed on the façade - and possibly where internal walls should be placed. It would be extremely interesting to know whether and in how far these triglyphs relate to the position of internal walls_-but at this moment there are no surveys which would enable us to answer this question.

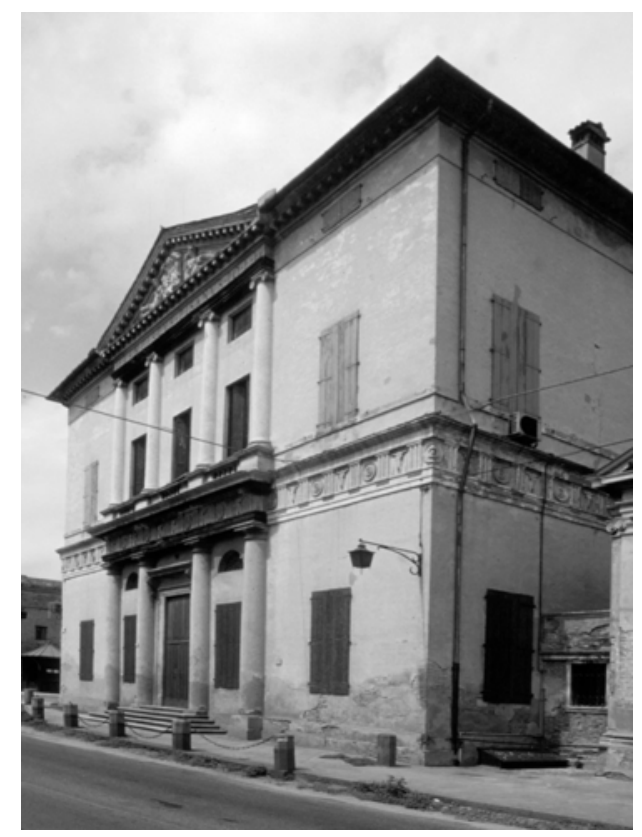

Fig. 10. Villa Pisani in Montagnana. (photo/author)

Ultimately, the result is that the mathematics of the orders became decisive for Palladio's design principles and the use of proportions from the early 1550s. It was combined with 
preferences for certain proportional relationships in the sense of ratios of lengths, widths and heights of rooms. But the thesis of the Modernist historiography, that when it comes to Palladio it is only the relationships between bare walls that matters, has to be rejected.

\section{Notes}

1. This article is based on the results of the survey of the Villa Cornaro made in June 2003 by Melanie Burke, Tim Ross, Steve Wassell and myself. I should like to express gratitude to the owners of the villa, Carl and Sally Gable, for the permission to survey the villa; to Professor Wolfgang Wolters for numerous advices in the preparation of the survey, Melanie Burke for the permission to reproduce two drawings she has produced subsequently to our survey, to my home institution, Unitec Institute of Technology, for the financial support in preparing the article, and to Ms. Karen Wise for the help with the written English of the article. The article was presented at the conference "Nexus 2004: Relationships Between Architecture and Mathematics", 19-23 June 2004 in Mexico City. For the full survey of the Villa Cornaro see the forthcoming book: Branko Mitrović and Steve Wassell (eds.), Andrea Palladio's Villa Cornaro in Piombino Dese (2005, in preparation).

2. [Beltramini and Guidolotti 2001] is particularly useful when it comes to providing the information necessary to separate original Palladio's works from later additions.

3. See [Mitrović 2004, 64-73 and 83-95] for a summary of these debates and further bibliography.

4. For statistical analyses of the second book of Palladio's treatise see [Howard and Longair 1982] and [Mitrović 2004, 64-65 and 190-198].

5. For the impact of Wittkower's book, see [Millon 1972] and [Payne 1994].

6. For a discussion of precision in Palladio's built work see [Robison 1998-1999].

\section{References}

AlberTi, Leon Battista. 1966. L'architettura. Ed. and Italian trans. Giovanni Orlandi. Milan: Edizioni Il Polifilo. (Parallel Latin/Italian version of De re aedificatoria). 1988. On the Art of Building. Trans. Joseph Rykwert, Robert Tavernor and Neil Leach. Cambridge, MA: MIT Press.

BARBARO, Daniele. 1987. I dieci libri dell'architettura tradotti et commentati. Facsimile of 2nd ed., Venice 1567. Milan: Il Polifilo.

Beltramini, Guido and Pino Guidolotti. 2001. Andrea Palladio atalante delle architetture. Venice: Marsilio.

Bertotti-Scamozzi, Ottavio. 1968. Le fabbriche e i disegni di Andrea Palladio (Vicenza 1796). New York: Architectural Book.

1998. Le fabbriche e $i$ disegni di Andrea Palladio. CD edition. Trans. Howard Burns. Vicenza: Centro Internazionale di Studi di Architettura "Andrea Palladio".

HowARD, Deborah and Malcolm LONGAIR. 1982. Harmonic Proportion and Palladio's Quattro Libri. Journal of the Society of Architectural Historians 41: 116-143.

LEWIS, Douglas. 1972. La datazione della villa Corner a Piombino Dese. Bollettino del Centro Internazionale di Studi di Architettura "Andrea Palladio"14: 381-393.

1975. Girolamo II Corner's Completion of Piombino with an unrecognized building of 1596 by Vincenzo Scamozzi. Bollettino del Centro Internazionale di Studi di Architettura "Andrea Palladio"17: 401-405.

Millon, Henry. 1972. Rudolf Wittkower, Architectural Principles in the Age of Humanism, Its Influence on the Development and interpretation of Modern Architecture. Journal of the Society of Architectural Historians, 31: 83-91.

Mitrović, Branko. 2001. A Palladian Palinode: Reassessing Rudolf Wittkower's Architectural Principles in the Age of Humanism. architectura 31: 113-131.

2002. Palladio's Canonical Corinthian Entablature and the Archaeological Surveys in the Fourth Book of I quattro libri dell'architettura. Architectural History 45: 113-127. 2004. Learning from Palladio. New York: W.W. Norton. 
Mitrović, Branko and Steve Wassell, eds. 2005. Andrea Palladio’s Villa Cornaro in Piombino Dese. Aalto Books and Unitec, New Zealand. In preparation.

PAlladio, Andrea. 1990. I quattro libri dell'architettura. (Venice, 1570). Facsimile ed. Milan: Ulrico Hoepli Editore.

1997. The Four Books on Architecture. Robert Tavernor and Richard Schofield, trans. Cambridge, MA: MIT Press.

1988. Scritti sull'architettura (1554-1579). Lionello Puppi, ed. Vicenza: Neri Pozza.

PAYNE, Alina. 1994. Rudolf Wittkower and Architectural Principles in the Age of Modernism. Journal of the Society of Architectural Historians, 53: 322-342.

RobIsON, Elwin. 1998-1999. Structural Implications in Palladio's Use of Harmonic Proportions. Annali d'architettura 10-11: 175-182.

WitTKOWER, Rudolf. 1962. Architectural Principles in the Age of Humanism. London: Warburg Institute.

\section{About the Author}

Branko Mitrović received his undergraduate degrees in Architecture and Philosophy from Belgrade University, his Ph.D. from University of Pennsylvania and currently teaches as Professor of Architectural History and Theory at Unitec Institute of Technology, Auckland, New Zealand. He is the author the book Learning from Palladio (Norton, New York 2004), the translation of and commentary on Vignola's Canon of the Five Orders (Acanthus, New York 1999) and a number of scholarly articles about Renaissance architectural theory. He has been awarded fellowships from Harvard University, Canadian Centre for Architecture and the Humboldt Foundation. 